\title{
https://doi.org/10.48009/1_iis_2005_332-338 \\ HOW DO IS PROGRAMS COMPARE WITH ABET ACCREDITED PROGRAMS?
}

\author{
Dr. Ronald J. MacKinnon, Georgia Southern University, rmackinn@ georgiasouthern.edu \\ Dr. E. Sonny Butler, Georgia Southern University, esbutler@georgiasouthern.edu
}

\begin{abstract}
As of February 2005 there were 11 IS programs at 10 universities accredited by ABET. This paper compares 10 of these accredited IS programs to a sample of 20 universities chosen from the 251 IS programs in the US listed by ISWorld. The data was collected by visiting the web pages of the selected universities. This paper includes a study of the required IS courses, elective IS courses, required programming courses, required business courses, title of the IS program (IS/MIS/CIS), and the department and college where the IS program is located. It is interesting to note that none of the accredited IS degrees are BBA degrees. This study points out several significant differences between the accredited IS programs and the typical BBA IS programs at the sample universities.
\end{abstract}

Keywords: ABET, CAC, IS accreditation, information systems

\section{INTRODUCTION}

Over the past few years there have been several interesting articles written about ABET accreditation of IS programs [1,2] at IACIS [7, 8] and ISECON [4, 5]. The Jones article [8] gives a good analysis of the IS curriculum at the 7 accredited universities at that time and Hilton $[4,5]$ gives an interesting analysis of AACSB and ABET accreditation. Since the Computing Accreditation Commission (CAC) of ABET approved formal criteria for accrediting IS programs in 2001, there have been 11 IS programs at 10 universities accredited by ABET. This paper looks at characteristics of these accredited universities and compares the characteristics at these universities to a sample of 20 other IS programs to see similarities and, more importantly, any significant differences between the accredited programs and the sample universities.

\section{METHODOLOGY AND DATA ANALYSIS}

As of February 2005 there were 251 universities with IS programs that were listed on the IS Departments web pages of ISWorld [8]. A sample of 20 of these universities were selected to compare with the accredited IS programs by selecting every $12^{\text {th }}$ university listed by ISW.

The analysis of the IS programs was done by examining the web pages of the selected universities. There is often a lag between changes in an IS curriculum and when these changes are listed on the department web pages, so the current IS curriculum requirements at a university may not be exactly in agreement with the department web pages. In comparing business requirements, there are wide variations on how colleges count business courses. At some universities economics is counted as a business course and at other universities it is counted as an arts course. At some universities programming is taught by the IS department and is counted as a required IS course. At other universities programming is taught by the Computer Science (CS) 
department and is counted as a required course but not counted as a required IS course. For this paper, the number of credits for IS, business and programming courses are counted as that university counts them.

\section{DEPARTMENT, TITLE AND COLLEGE}

Table 1 lists the departments, titles of the IS courses and the college where the accredited IS programs belong to.

Table 1. ABET Accredited Universities Departments

\begin{tabular}{llll} 
University & Department & IS Title & College \\
\hline Drexel U & None & IS & IS \& Technology \\
Illinois State U & None & MIS & School of IT \\
Kennesaw State U & CS \& IS & IS & College of Science \& Math \\
U of Nebraska, Omaha & IS \& Quant & MIS & IS \& Technology \\
NJ Institute of Tech & IS & IS & College of Computing Sciences \\
U of North Florida & C \& IS Sciences & IS & College of Engin \& Construction \\
Pace U & None & IS & School of CS \& IS \\
Robert Morris U & CIS & ISM & School of Comm \& IS \\
U of South Alabama & None & C \& IS & School of Computer \& IS \\
Virginia Commonwealth U & IS & IS & School of Business
\end{tabular}

Three of the accredited programs do not belong to any department and the other accredited programs belong to typical IS departments. The titles of the IS courses are also typical, but the college where the IS program belongs is not typical. It should be noted that at 9 of these universities, the accredited IS program is not housed in a college of Business. Only Virginia Commonwealth has its IS program in a College of Business.

Table 2 lists the sample universities and the equivalent information for the sample universities. It can be seen that the departments where the IS programs are located are typical and the title of the IS courses are also typical. However, it should be noted that almost all the IS programs from the sample universities are located in colleges or schools of business. This is a major difference between the accredited IS programs and the sample IS programs. 
Table 2. Sample IS Departments

\begin{tabular}{|c|c|c|c|}
\hline University & Department & IS Title & College \\
\hline Baylor U & IS & ISY & $\mathrm{COB}$ \\
\hline Bowling Green SU & A \& MIS & MIS & CBA \\
\hline Central Connecticut SU & MIS & MIS & SOB \\
\hline Colorado State U & CIS & $\mathrm{BD}$ & $\mathrm{COB}$ \\
\hline Eastern Michigan U & CIS & ISM & $\mathrm{COB}$ \\
\hline Florida Gulf Coast U & CIS & ISM & $\mathrm{COB}$ \\
\hline Georgia College \& SU & IS,C \& M & CBIS & $\mathrm{COB}$ \\
\hline James Madison & IT \& MS & CIS & $\mathrm{COB}$ \\
\hline Louisiana State U & IS \& DS & ISDS & $\mathrm{COB}$ \\
\hline Middle Tennessee SU & CIS & CIS & $\mathrm{COB}$ \\
\hline Northwest Missouri SU & CS/IS & MIS & $\mathrm{COB}$ \\
\hline Oklahoma State U & MS \& IS & MIS & $\mathrm{COB}$ \\
\hline San Diego State U & IDS & IDS & $\mathrm{COB}$ \\
\hline Temple U & MIS & MIS & SOB \\
\hline U of Alabama, Huntsville & None & MIS & CAS \\
\hline U of Central Florida & MIS & MIS & $\mathrm{COB}$ \\
\hline $\mathrm{U}$ of Maryland, BC & IS & IS & None \\
\hline U New Mexico & M,IS \& DS & MGT & SOM \\
\hline U of South Florida & IS DS & MIS & $\mathrm{COB}$ \\
\hline Western Carolina U & BCIS \&Econ & CIS & $\mathrm{COB}$ \\
\hline
\end{tabular}

\section{IS DEGREE NAME AND BUSINESS CREDITS REQUIRED}

Table 3 lists the title of the IS programs at the accredited universities and also lists whether the university has a CS degree and the number of business credits required and whether the university also offers a BBA in IS degree. It is notable that none of the accredited IS programs had an accredited BBA IS degree. Nine of the degrees are BS degrees and one is a BIS degree. The business credits average 20.7-21.8, which is a relatively low number of business credits for an IS degree. It is also interesting to note that two of the universities also offer a BBA IS degree, but this program is not accredited. 
Table 3. ABET IT Degrees \& Business Credits Required

\begin{tabular}{lcccc} 
University & $\begin{array}{c}\text { IS } \\
\text { Degree }\end{array}$ & $\begin{array}{c}\text { CS } \\
\text { Degree }\end{array}$ & $\begin{array}{c}\text { Business } \\
\text { Credits } \\
\text { Required }\end{array}$ & $\begin{array}{c}\text { BBA IS } \\
\text { Also? }\end{array}$ \\
\hline Drexel U & BS & Y & 27 & Y \\
Illinois State U & BIS & Y & 22 & BIS \\
Kennesaw State U & BS & Y & 27 & N \\
U of Nebraska, Omaha & BS & Y & 20 & N \\
NJ Institute of Tech & BS & Y & 15 & N \\
U of North Florida & BS & Y & 12 & N \\
Pace U & BS & Y & $6+17$ opt & Y \\
Robert Morris U & BS & SE & 15 & N \\
U of South Alabama & BS & Y & 24 & N \\
Virginia Commonwealth U & BS & Y & 39 & N \\
Average & & & $20.7-21.8$ &
\end{tabular}

Table 4 lists the equivalent data from the sample universities. It is obvious that most of the IS degrees are BBA degrees and only 3 of the sample universities offer a BS in IS degree. All the sample universities also offer a CS degree. It is notable that the number of business credits required is higher than the accredited universities. The average number of business credits for the sample universities is 38.3, which is much higher than the ABET accredited universities. 
Table 4. Sample Universities IT Degrees \& Business Credits Required

\begin{tabular}{|c|c|c|c|}
\hline University & $\begin{array}{c}\text { IS } \\
\text { Degree }\end{array}$ & $\begin{array}{c}\text { CS } \\
\text { Degree }\end{array}$ & $\begin{array}{c}\text { Business } \\
\text { Credits } \\
\text { Required }\end{array}$ \\
\hline Baylor U & $\mathrm{BBA}$ & $\mathrm{Y}$ & 54 \\
\hline Bowling Green SU & $\mathrm{BS}$ & $\mathrm{Y}$ & 57 \\
\hline Central Connecticut SU & $\mathrm{BBA}$ & $\mathrm{Y}$ & 27 \\
\hline Colorado State U & BBA & $\mathrm{Y}$ & 33 \\
\hline Eastern Michigan U & $\mathrm{BBA}$ & $\mathrm{Y}$ & 36 \\
\hline Florida Gulf Coast U & $\mathrm{BBA}$ & $\mathrm{Y}$ & 30 \\
\hline Georgia College \& SU & $\mathrm{BBA}$ & Y & 18 \\
\hline James Madison & BBA & Y & 39 \\
\hline Louisiana State U & BBA & $\mathrm{Y}$ & 36 \\
\hline Middle Tennessee SU & $\mathrm{BBA}$ & $\mathrm{Y}$ & 45 \\
\hline Northwest Missouri SU & $\mathrm{BBA}$ & $\mathrm{Y}$ & 33 \\
\hline Oklahoma State U & $\mathrm{BBA}$ & $\mathrm{Y}$ & 36 \\
\hline San Diego State U & BBA & $\mathrm{Y}$ & 33 \\
\hline Temple U & $\mathrm{BBA}$ & $\mathrm{Y}$ & 58 \\
\hline U of Alabama, Huntsville & $\mathrm{BBA}$ & Y & 48 \\
\hline U of Central Florida & $\mathrm{BBA}$ & $\mathrm{Y}$ & 45 \\
\hline U of Maryland, BC & $\mathrm{BS}$ & Y & 18 \\
\hline U of New Mexico & $\mathrm{BBA}$ & $\mathrm{Y}$ & 36 \\
\hline U of South Florida & $\mathrm{BA} / \mathrm{BS}$ & $\mathrm{Y}$ & 39 \\
\hline Western Carolina U & BSBA & $\mathrm{Y}$ & 45 \\
\hline Average & & & 38.3 \\
\hline
\end{tabular}

\section{REQUIRED IS AND PROGRAMMING CREDITS}

Table 5 lists the required IS credits, the IS elective credits, the total IS credits and the number of programming credits required. Table 6 lists the equivalent credits for the sample universities. It is very obvious that the accredited universities have a much higher requirement of IS courses for their degree: in some cases they require twice as many IS credits as some of the IS programs at the sample universities do. The programming requirements are similar but are often higher at the accredited programs. 
Table 5. ABET IS Requirements

\begin{tabular}{lcccc} 
University & $\begin{array}{c}\text { IS Credits } \\
\text { Required }\end{array}$ & $\begin{array}{c}\text { IS Credits } \\
\text { Electives }\end{array}$ & $\begin{array}{c}\text { IS Credits } \\
\text { Total }\end{array}$ & $\begin{array}{c}\text { Programming } \\
\text { Credits Required }\end{array}$ \\
\hline Drexel & 41 & 16 & 56 & 9 \\
Illinois State & 22 & $20-23$ & $42-45$ & 9 \\
Kennesaw State & 34 & $9-15$ & $43-49$ & 9 \\
Nebraska, Omaha & 33 & 12 & 45 & 4 \\
NJ Institute of Tech & 42 & 15 & 57 & 6 \\
North Florida & 27 & 12 & 39 & 11 \\
Pace & 39 & 6 & 45 & 12 \\
Robert Morris & 27 & 12 & 39 & 3 \\
South Alabama & 50 & 9 & 59 & 6 \\
Virginia Commonwealth & 30 & 9 & 39 & 6 \\
Average & 34.5 & $12-12.9$ & $46.4-47.3$ & 7.5
\end{tabular}

Table 6. Sample Universities IS Requirements

\begin{tabular}{lcccc} 
University & $\begin{array}{c}\text { IS Credits } \\
\text { Required }\end{array}$ & $\begin{array}{c}\text { IS Credits } \\
\text { Electives }\end{array}$ & $\begin{array}{c}\text { IS Credits } \\
\text { Total }\end{array}$ & $\begin{array}{c}\text { Programming } \\
\text { Credits Required }\end{array}$ \\
\hline Baylor U & $12-24$ & 6 & $18-30$ & 3 \\
Bowling Green SU & 24 & 6 & 30 & 6 \\
Central Connecticut SU & 27 & 6 & 33 & 3 \\
Colorado State U & 24 & 3 & 27 & 6 \\
Eastern Michigan U & 27 & 3 & 30 & 6 \\
Florida Gulf Coast U & 27 & 6 & 33 & 9 \\
Georgia College \& SU & 21 & 3 & 24 & 3 \\
James Madison & 25 & $12-15$ & $37-40$ & 9 \\
Louisiana State U & 30 & 9 & 39 & 3 \\
Middle Tennessee SU & 21 & 9 & 30 & 6 \\
Northwest Missouri SU & 27 & 0 & 27 & 6 \\
Oklahoma State U & 18 & $3-12$ & $21-30$ & 6 \\
San Diego State U & 24 & 6 & 30 & 6 \\
Temple U & $30-31$ & 3 & $33-34$ & 6 \\
U of Alabama, Huntsville & 21 & 6 & 27 & 3 \\
U of Central Florida & 21 & 6 & 27 & 9 \\
U of Maryland, BC & 24 & 3 & 27 & 9 \\
U New Mexico & 21 & 9 & 30 & 9 \\
U of South Florida & 18 & 6 & 24 & 6 \\
Western Carolina U & 21 & 3 & 24 & 6.2 \\
Average & $23.2-24.9$ & $5.4-6.0$ & $27.3-29.8$ &
\end{tabular}




\section{CONCLUSION}

In comparing the ABET accredited IS programs to the sample universities, several items stand out. Most of the accredited IS programs are BS degrees and are not bound by the AACSB regulations. The accredited IS programs are not usually located in a college of business. By contrast, all of the sample universities are located in colleges or schools of business and are required to have a certain number of business credits, and in the past the " $50 \%$ rule" of AACSB restricted the number of credits that were available in a major field. This is emphasized in the lower number of business credits in accredited programs and the higher number of IS credits in accredited programs. From Tables 3, 4, 5 and 6 it appears that accredited IS programs have replaced some typical business credits in IS programs by additional IS credits, thus producing a stronger technically oriented IS program. It appears that the first IS programs evaluated by ABET were evaluated by computer science professors accustomed to evaluating technically strong computer science programs.

It appears that a technically strong IS program would have a better chance of being accredited. It will be interesting to see the first BBA IS programs that are accredited to see if the number of IS credits are comparable to the IS credits in the current accredited IS programs. If a university with an IS program is considering ABET accreditation they should read the Kohun and Wood [6] article carefully to learn from the experiences with ABET accreditation at Robert Morris University.

\section{REFERENCES}

1. ABET Accredited Computing Programs http://www.abet.org/accredited_programs/computing/schoolarea.asp

2. ABET Computing Accreditation Commission (2004), Criteria for Accrediting Computing Programs, November 1, 2004.

3. IS Departments, ISWorld http://juliet.stfx.ca/ rmackinn/infosys/na.htm\#usa

4. Hilton, T. S. E. (2003). MIS Program Accreditation: Comparing AACSB and ABET, ISECON 2003, 20

5. Hilton, T. S. E., Johnson, D. A., \& Kasper, G. M. (2004). ABET Accreditation of MIS Programs in AACSB Schools, ISECON 2004, 21, 1-16.

6. Kohum, F. G., \& Wood, D. F. (2003). The ABET CAC Accreditation Experience - Intent and Reality - the Information Systems Perspective. Information Systems Education Journal, 1(43), 3-11.

7. Kohum, F. G., \& Wood, D. F. (2004). The ABET CAC Accreditation: Is Accreditation Right for Information Systems? IACIS 2004, V(2), 579-583.

8. Jones, C. G. (2004). An Analysis of Programmatic Differences Between Dual ABET/AACSB and ABET-Only Accredited Information Systems Programs, IACIS 2004, 2 , 544-530. 